\title{
Molecular Systematic Investigations of Three Fin Fish Cichlid Species of Oreochromis niloticus (Nile Tilapia), Genetically Improved Farmed Tilapia (GIFT) and Astronotus ocellatus (Oscar Cichlid)
}

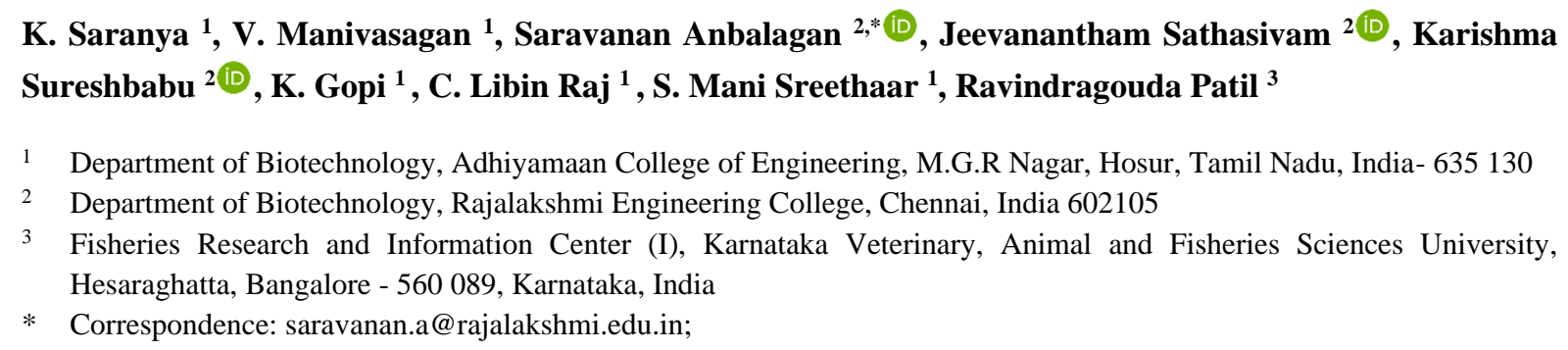

Scopus Author ID 56950442900

Received: 15.02.2021; Revised: 28.03.2021; Accepted: 4.04.2021; Published: 9.05.2021

\begin{abstract}
Fisheries in India contribute significantly to the total GDP of agriculture and earn significant foreign exchange. Aquaculture is playing an important role in India and is bestowed with a huge biodiversity of aquatic organisms. India ranks second in total fish production in the world. Nile tilapia has become the world's second most popular farmed fish, after carps. Oscars is a popular aquarium fish around the world. In the present study, efforts were made to analyze the extent of divergence or similarity among three cichlid finfishes (Nile Tilapia, GIFT Tilapia, and Oscar Cichlid) using molecular biology techniques such as Random Amplification of Polymorphic DNA (RAPD) and Restriction Fragment Length Polymorphism (RFLP). The Phylogenetic tree was constructed using PhyElph software to study the evolutionary relationship between the three cichlid finfish species. The Phylogenetic or evolutionary relationship was established for the three fishes, Nile tilapia, GIFT, and Oscar cichlid, with the Phylogenetic tree. It was found that Nile tilapia and GIFT share a recent common ancestor, while Oscar cichlid does not share any evolutionary relationship with Nile tilapia and GIFT.
\end{abstract}

Keywords: Nile tilapia; Oscar; GIFT; cichlid; aquaculture; RAPD; RFLP; Phylogenetic tree

(C) 2021 by the authors. This article is an open-access article distributed under the terms and conditions of the Creative Commons Attribution (CC BY) license (https://creativecommons.org/licenses/by/4.0/).

\section{Introduction}

More than 70 percent of the earth's surface is covered with water. The aquatic resources are rich in biodiversity and contribute greatly to the high protein dietary requirement of the ever-increasing global population. Fish is one the primary source of protein and an important part of the diet worldwide (UNEP) due to its higher nutritional value. Globally, fish contributes to $16 \%$ of humans' total animal protein intake and is rich in minerals and essential fatty acids. Fish has two different omega-3 fatty acids as DHA (docosahexaenoic acid) and EPA (eicosapentaenoic acid). Therefore, it is considered the primary source of omega-3 fatty acids in the human diet and contains vitamins like D, B2 (riboflavin), and minerals such as iodine, iron, and magnesium, potassium, zinc [1]. The presence of various nutrients, vitamins, and minerals in fish can reduce the risk of stroke and heart attack in humans by dropping blood pressure levels. In some countries, such as Bangladesh, Cambodia, Gambia, Sri Lanka, and 
Small Island Developing States (SIDS), fish make up $50 \%$ or more of people's protein intake. On the global level, the fisheries sector provides nearly 60 million people with direct employment. The fisheries and aquaculture sector also aim to tackle hunger, malnutrition, poverty and contribute to the economic growth in the world. It also focuses on the conservation of resources, biodiversity, and the environment to address the well-being and livelihood of people working in this sector [2]. Fish and aquaculture production continues to expand, increasing from 171 million tonnes to 201 million tonnes by 2030 (18\% increase).

There are different factors such as temperature, salinity, ammonia, and dissolved oxygen level in water that affect aquatic animals' growth and propagation [3]. The growth and metabolic rate of the fish in the aquatic environment strongly depend on the water temperature. Up to a certain (optimum) limit, an increase in temperature increases the growth and metabolic rate of fish, but beyond an optimum condition, it affects these rates by lowering the availability of dissolved oxygen (DO) concentration. In addition to that, pollutants in the aquatic environment are more toxic at a higher temperature which causes harmful health effects to aquatic animals and humans via the food web [4]. Water salinity is one of the key factors which control the growth rate of fish. The salinity of water varies from 0.7 to $33 \mathrm{~g} / \mathrm{L}$. For the freshwater, salinity should be less than $0.7 \mathrm{~g} / \mathrm{L}$; if it exists beyond $0.7 \mathrm{~g} / \mathrm{L}$ will alter the physiological characteristics of aquatic animals in the freshwater eco-system (lakes and rivers). In the seawater, salinity can also alter the water density and temperature, which results in climate change, and an average salinity level in seawater is $35 \mathrm{~g} / \mathrm{L}[5,6]$. The abundant availability of a higher concentration of ammonia in the aquatic ecosystem directly affects the growth and development of aquaculture. Because they can accumulate in the internal tissues of aquaculture, especially fish, and decreases their growth and feed uptake rate [7-9]. Dissolved oxygen (DO) is one of the essential factors for the survival of any species in the aquatic environment. It is also required to decompose organic matters in an aquatic environment. DO should be maintained around $8.0 \mathrm{mg} / \mathrm{L}$ for freshwater aquaculture and $6.0-7.0 \mathrm{mg} / \mathrm{L}$ for marine aquaculture. Even lower and excess DO concentration causes greater stress on aquatic animals and also causes various harmful neurotic diseases like gas bubble disease to the aquatic animals [10].

Cichlids are mostly freshwater fishes of family Cichlid were found in tropical America, mainland Africa, south Asia, and Madagascar. Oreochromis niloticus (Nile tilapia) is one of the well-known cichlid species, has higher market demand due to its better meat quality among other freshwater aquaculture [11-13]. Nile tilapia is a freshwater cichlid native to the Nile River basin, can grow under an optimal environmental condition; the south-western Middle East; the Niger, Benue, Volta, and Senegal rivers, and the lakes Chad, Tanganyika, Albert, Edward, and Kivu. The genetically improved farmed tilapia (GIFT) is the genetically modified Oreochromis niloticus strain. It was introduced to overcome the limitations of the traditional O. niloticus strain and meet the animal protein demand of freshwater aquaculture. GIFTs are monosex males; therefore, they can grow significantly faster than the traditional $O$. niloticus and female tilapia $[14,15]$. In the female tilapia, most of the energy has been utilized for their reproductive activities, such as egg production and spawning activity. Therefore, female tilapia could not be able to produce uniform-sized species in a shorter period of time. But in the case of GIFT, due to its monosex male in nature, the complete energy drawn from the feeds was utilized for their growth and development. Therefore, GIFT fish produce a high yield with uniformed size within a short period of time $[16,17]$. GIFT fish's growth and survival were $60 \%$ and $50 \%$ higher than the traditionally farmed fishes. They can also grow even at wide environmental conditions, 
suitable for small scale and large scale production, and has a higher resistance to diseases and deprived water quality. Thereby, GIFT contributes to the Indian economy in the fishery sector [18-20]. Astronotus ocellatus (Oscar) is one of the ornamental freshwater fish and survives in freshwater with a warm temperature of $25^{\circ} \mathrm{C}$ in the sandy substrate or muddy area. Oscar is mostly found in calm, shallow freshwater rivers and basins and native to South America [21].

The present investigation aims to study the evolutionary relationship and genetic variation between the three different freshwater cichlid finfishes (Oreochromis niloticus, GIFT of O.niloticus, and Astronotus ocellatus). The genetic variation between these three cichlid fishes was explained by performing Restriction fragment length polymorphism (RFLP) and Random Amplified Polymorphic DNA (RAPD) analysis of their extracted genomic DNA. To explain the evolutionary relationship between these three cichlid fishes, phylogenetic tree was constructed using PyElph software.

\section{Materials and Methods}

\subsection{Collection of samples.}

Genetically Improved Farmed Tilapia (GIFT), Oreochromis niloticus (Nile tilapia), Astronotus ocellatus (Oscar) samples were collected from Fisheries Research and Information Centre (FRIC), Karnataka Veterinary Animal and Fisheries Sciences University (KVAFSU), Hesaraghatta, Bangalore, Karnataka, India. The images of three cichlid fishes were shown in Figure 1. The fish samples were anesthetized using 3 drops of clove oil. $2 \mathrm{~g}$ of muscle sample was collected from the individual fish and transferred aseptically into a labeled Eppendorf tube and preserved in absolute ethanol for further studies.

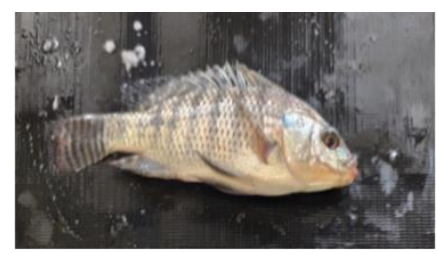

(a)

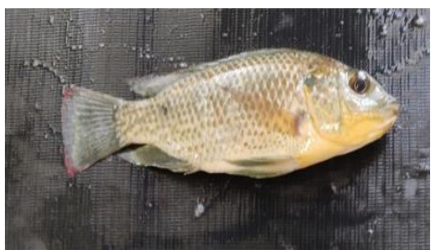

(b)

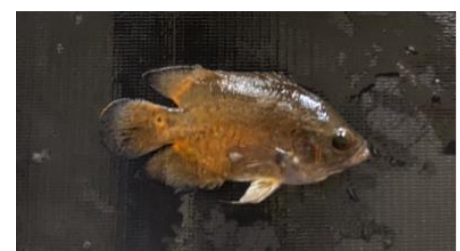

(c)

Figure 1. Images of three species of cichlid fishes used in the study: (a) Genetically Improved Farmed Tilapia (GIFT); (b) Oreochromis niloticus (Nile tilapia); (c) Astronotus ocellatus (Oscar).

\subsection{Meristic characteristics.}

Meristic characters in fishes are important to the differentiation of taxonomic units and can spot differences between fish populations. Meristic characters are countable fish characters such as fin rays, fin spines, and Gill slits. The meristic character analyses are performed in dead fishes GIFT, Oreochromis niloticus (Nile tilapia), and Astronotus ocellatus (Oscar). The meristic characters are studied under the microscope for better accuracy.

\subsection{Extraction of genomic DNA.}

For the extraction of genomic DNA, $50 \mathrm{mg}$ of caudal fin tissues were isolated from three cichlid species (GIFT, Nile tilapia, and Oscar) and suspended in $500 \mu \mathrm{L}$ of STE buffer mixture ( $\mathrm{pH} 8.0$ ), which contains $0.1 \mathrm{M} \mathrm{NaCl}, 0.05 \mathrm{M}$ Tris and $0.01 \mathrm{M}$ of EDTA. To the DNA buffer mixture, $30 \mu \mathrm{L}$ of SDS and $30 \mu \mathrm{L}$ of $10 \mathrm{mg} / \mathrm{L}$ of protease $\mathrm{K}$ were added and incubated for $30 \mathrm{~min}$ at $50{ }^{\circ} \mathrm{C}$. After incubation, DNA was purified with different ratios of phenol, chloroform, and isoamyl alcohol (25:24:1). The purified pellet of DNA was washed with $70 \%$ 
absolute ethanol and resuspended in $150 \mu \mathrm{L}$ of Tris-EDTA buffer of $\mathrm{pH}$ 7.2. The concentration of genomic DNA was estimated using UV-VIS Spectrophotometer at $260 \mathrm{~nm}$. The isolated genomic DNA from fish tissue was checked with $2 \%$ agarose gel [22].

\subsection{RAPD analysis.}

The RAPD analysis of genomic DNA of three fishes GIFT, Oreochromis niloticus (Nile tilapia), Astronotus ocellatus (Oscar), was carried out by subjecting extracted DNA samples to PCR amplification using OPA10, OPA08, and OPA04 primers. These primers were used to study variation in Oreochromis species. The PCR amplification of three cichlid DNA samples was carried out as 45 cycles of different thermal cycling conditions such as (i) Denaturation (94 ${ }^{\circ} \mathrm{C}$ for $30 \mathrm{~s}$ ), (ii) Annealing $\left(55^{\circ} \mathrm{C}\right.$ for $30 \mathrm{~s}$ ), and (iii) Extension $\left(72{ }^{\circ} \mathrm{C}\right.$ for $\left.10 \mathrm{~min}\right)$. The amplified PCR products were purified by removing the unincorporated dNTPs and primers from the PCR product by using a Montage PCR clean-up kit. The amplified and purified DNA fragments were separated by performing agarose gel-electrophoresis using $2 \%$ agarose gel and visualized on UV transilluminator [23].

\subsection{Construction of phylogenetic tree.}

The DNA bands were generated from the RAPD analysis of three fishes GIFT, Oreochromis niloticus (Nile tilapia), Astronotus ocellatus (Oscar), using three primers were analyzed by PyElph gel image analysis program for the construction of phylogenetic tree [24]. A dendrogram was constructed based on genetic identity and genetic distance using the unweighted pair group average (UPGMA) clustering method.

\subsection{Amplification and Isolation of $18 S$ rRNA gene.}

The genomic DNA of three fishes, GIFT, Oreochromis niloticus (Nile tilapia), Astronotus ocellatus (Oscar) were subjected to PCR amplification of 18S rRNA gene using SSU I and SSU II primers [25]. For the amplification of 18S rRNA gene, 5 ng of genomic DNA from each of the three fishes was taken to which $25 \mu \mathrm{L}$ of PCR reaction mixtures were added, which comprises of $2.5 \mu \mathrm{L}$ of $10 \mathrm{x}$ PCR buffer, $1.5 \mu \mathrm{L}$ of dNTP mixtures, $2 \mu \mathrm{L}$ primer, $20 \mathrm{ng}$ DNA template, $0.5 \mu \mathrm{l}$ Taq DNA polymerase $(1.25 \mathrm{U})$, and $16 \mu \mathrm{L}$ distilled water. PCR amplification of genomic DNA was performed as five phases such as initial denaturation, denaturation, annealing, extension and final extension at the following conditions; $94{ }^{\circ} \mathrm{C}$ for 5 min, $94{ }^{\circ} \mathrm{C}$ for $30 \mathrm{sec}, 56{ }^{\circ} \mathrm{C}$ for $30 \mathrm{sec}, 72{ }^{\circ} \mathrm{C}$ for $2 \mathrm{~min}$ and $72{ }^{\circ} \mathrm{C}$ for $10 \mathrm{~min}$ respectively in the programmed Eppendorf Master cycle. Reaction tubes were held at $4{ }^{\circ} \mathrm{C}$. The visualization of PCR product was electrophoresed on a $1.5 \%$ agarose gel stained with ethidium bromide. 18S rRNA gene was isolated from PCR products by the Glassmilk DNA purification method from the electrophoresed agarose gel.

\subsection{RAPD analysis of $18 S$ rRNA gene.}

The extracted 18S rRNA gene from three fin cichlid fishes was subjected to restriction digestion using the EcoRI. $25 \mu \mathrm{L}$ of restriction digestion reaction mixture was comprised of $100 \mathrm{ng}$ 18S rRNA ,10x assay buffer, and 0.5 units of EcoRI, SmaI, and AvaI restriction enzymes, respectively. The restriction digestion reaction for EcoRI and AvaI product was incubated at $37{ }^{\circ} \mathrm{C}$ for $2 \mathrm{~h}$, and SmaI was incubated at $30{ }^{\circ} \mathrm{C}$ for $2 \mathrm{~h}$ [26]. The restriction digestion products were subjected to gel electrophoresis using $2 \%$ agarose gel with standard 
DNA markers (10,000 bp to $100 \mathrm{bp})$. The bands were visualized using a UV transilluminator, and the image was captured using a gel documentation unit.

\section{Results and Discussion}

\subsection{Meristic characteristics.}

The Meristic characters, such as a number of the dorsal fin, anal fin, and gills of GIFT, Nile tilapia, and Oscar fishes, were listed in Table 1. Nile tilapia contained a total of $16-17$ dorsal spines and 11 - 15 dorsal rays. The number of anal spines was 3 , and anal fin rays ranged from 10-11 for Nile tilapia. In the case of GIFT, the number of dorsal fin spines was 16, dorsal fin rays were 13, and the number of anal fin spines and rays was found to be 3 and 9, respectively. In the Oscar cichlid, the number of dorsal fin spines was 12, and the rays were 21. The anal fin spines and rays of Oscar cichlid were 3 and 19, respectively. The gill rakers images of three cichlid species were shown in Figure 2.

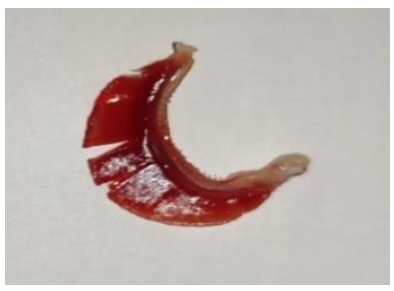

(a)

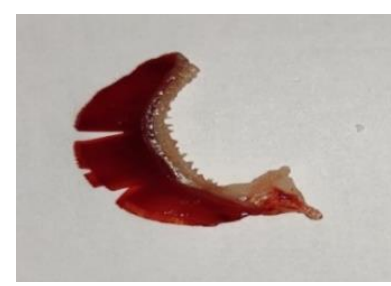

(b)

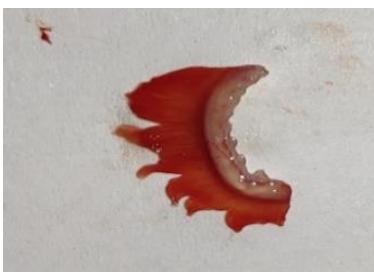

(c)

Figure 2. Gill rakers image of three species of cichlid fishes: (a) Genetically Improved Farmed Tilapia (GIFT); (b) Oreochromis niloticus (Nile tilapia); (c) Astronotus ocellatus (Oscar).

Table 1. Meristic differences between the three finfishes of cichlid species.

\begin{tabular}{l|c|c|c|c|c}
\multirow{2}{*}{ Fish species } & \multicolumn{2}{|c|}{ Dorsal fin (No.s) } & \multicolumn{2}{c}{ Anal fin (No.s) } & \multirow{2}{*}{ Gills (No.s) } \\
\cline { 2 - 5 } & Spines & Rays & Spines & Rays & \\
\hline Nile Tilapia & $16-17$ & $11-15$ & 3 & $10-11$ & $27-33$ \\
\hline GIFT & 16 & 13 & 3 & 9 & $24-25$ \\
\hline Oscar & 12 & 21 & 3 & 19 & $10-11$
\end{tabular}

\subsection{Extraction of genomic DNA.}

The genomic DNA was extracted from GIFT, Oreochromis niloticus (Nile tilapia), Astronotus ocellatus (Oscar). The concentration of genomic DNA was estimated using UVVIS Spectrophotometer at $260 \mathrm{~nm}$. The gel-electrophoresis results of isolated genomic DNA from three cichlid species were shown in Figure 3. From Figure 3, lane 1, lane 2, and lane 3 indicated the presence of isolated DNA from GIFT, Nile tilapia, and Oscar fish, respectively.

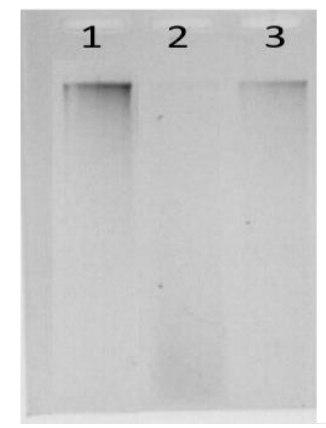

Figure 3. Isolated genomic DNA from GIFT (Lane 1), Oreochromis niloticus (Lane 2), Astronotus ocellatus (Lane 3). 


\subsection{RAPD analysis.}

The RAPD analysis of genomic DNA of three cichlid species was subjected to PCR amplification using OPA10, OPA08, and OPA04 primers. The details of three different primers, such as OPA10, OPA08, and OPA04 used for RAPD analysis, were listed in Table 2. The features of three primers used for RAPD analysis of 18S rRNA gene were presented in Table 3. The primers were monitored to generate a fingerprint banding pattern and assess polymorphism among three cichlid species. All primers produced a total of 34 amplified bands with an average of 11.3 bands per primer. Among them, 7 bands were the common exhibiting a low level of monomorphism of $20.657 \%$, and 37 bands were polymorphic, displaying a high level of polymorphism of $79.33 \%$, an average number of polymorphic fragments per primer is 12.3. An instructive RAPD fingerprint profile was generated by the 16 primers with various band size lengths ranging from $100 \mathrm{bp}$ to $4000 \mathrm{bp}$ compared to a $100 \mathrm{bp}$ step up ladder and 500 bp step up the ladder.

Table 2. Details of the random primers used for RAPD analysis.

\begin{tabular}{c|c|c|c} 
Primer Name & Primer Sequence & GC $\%$ & $\mathbf{T}_{\mathbf{m}}\left({ }^{\circ} \mathbf{C}\right)$ \\
\hline OPA 10 & GTGATCGCAG & 60 & 25 \\
\hline OPA 08 & GTGACGTAGG & 60 & 25 \\
\hline OPA 04 & AATCGGGCTG & 60 & 25
\end{tabular}

Table 3. Features of three primers (OPA 10, OPA 08, and OPA 04) used for RAPD analysis of 18S rRNA gene.

\begin{tabular}{|c|c|c|c|c|c|c|c|c|c|}
\hline \multirow{2}{*}{ Primer code } & \multicolumn{3}{|c|}{ Number of the amplified band } & \multirow{2}{*}{$\begin{array}{c}\text { TNA } \\
\text { Bands }\end{array}$} & \multirow{2}{*}{$\begin{array}{c}\text { NP } \\
\text { Bands }\end{array}$} & \multirow{2}{*}{$\begin{array}{c}\text { NM } \\
\text { Bands }\end{array}$} & \multirow{2}{*}{$\begin{array}{l}\text { Band freq/ } \\
\text { primer }\end{array}$} & \multirow[t]{2}{*}{$\% \mathbf{P}$} & \multirow{2}{*}{$\begin{array}{c}\text { RA } \\
\text { Bands (bp) }\end{array}$} \\
\hline & GIFT & Nile tilapia & Oscar & & & & & & \\
\hline OPA 10 & 9 & 8 & 9 & 10 & 8 & 2 & 0.294 & 80 & $200-1600$ \\
\hline OPA 08 & 9 & 8 & 7 & 12 & 10 & 2 & 0.353 & 83.33 & $200-2500$ \\
\hline OPA 04 & 10 & 11 & 9 & 12 & 9 & 3 & 0.353 & 75 & $300-3100$ \\
\hline Total & 28 & 27 & 25 & 34 & 27 & 7 & - & 79.44 & - \\
\hline Band freq/species & 0.824 & 0.794 & 0.735 & - & - & - & - & - & - \\
\hline
\end{tabular}

Three primers, such as OPA10, OPA08, and OPA04 produced 8, 10, and 9 numbers of polymorphic bands, respectively. The highest number of polymorphic bands (10) was generated with primer OPA08. The band frequency per species was $0.824,0.794$, and 0.735 for GIFT, Oreochromis niloticus (Nile tilapia), Astronotus ocellatus (Oscar), respectively, while band frequency for each primer was from 0.294 to 0.353 . The RAPD genotyping profile obtained for cichlid species with 3 primers is shown in Figure 4. From Figure 4, lane 4 and lane 5 show the polymorphic bands of the $100 \mathrm{bp}$ and $500 \mathrm{bp}$ of step-up ladders, respectively.

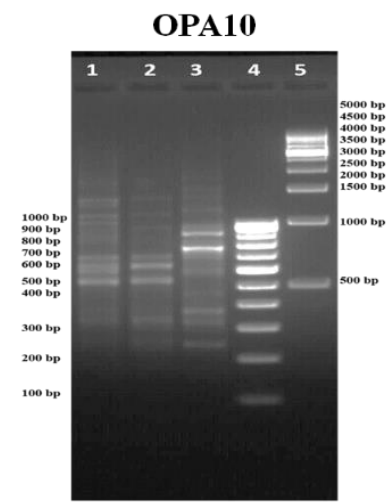

(a)

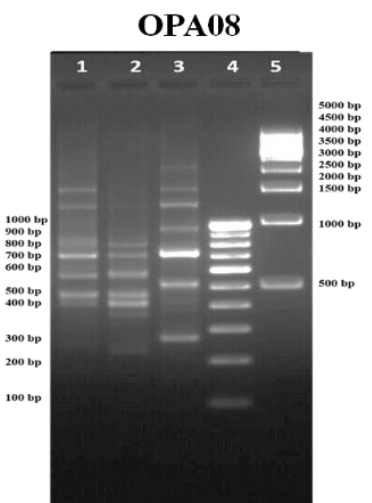

(b)

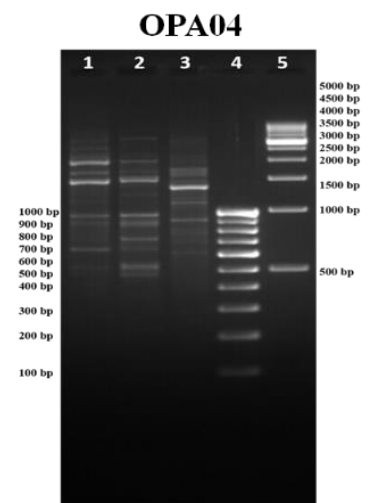

(c)

Figure 4. The generated RAPD amplification products of GIFT (Lane 1), Oreochromis niloticus (Lane 2), Astronotus ocellatus (Lane 3) using three different primers: (a) OPA10; (b) OPA08; (c) OPA04. 


\subsection{Construction of phylogenetic tree.}

RAPD analysis was used to construct the phylogenetic tree to find an evolutionary relationship among GIFT, Nile tilapia, Oscar fishes. The genetic difference among the three cichlid species might be due to each genus' evolutionary relationship, habitat, temperature, and phenotype. All three primers OPA10, OPA08, and OPA04, produced polymorphic bonds with Nile tilapia, GIFT, and Oscar tilapia. From Figure 4, the bands at different base pairs indicated the molecular weight of respective DNA fragments of three cichlid species. The evolutionary relationship among the three cichlid species was explained by constructing a phylogenetic tree using the three primers such as OPA10, OPA08, and OPA04. The constructed phylogenetic trees of three different primers were shown in Figure 5. From Figure 5, it was proved that Nile Tilapia and GIFT are the recent common ancestors among them. The reason for that kind of conclusion was the formation of internodes by both Nile tilapia and GIFT in all the three phylogenetic trees. When two or more species from an internode in a phylogenetic tree show that those species within these nodes share a common ancestor. Thus it can be concluded that Nile tilapia and GIFT share a very recent common ancestor, but in the case of Oscar cichlid, it did not form any nodes with Nile tilapia or GIFT. This showed that Oscar cichlid does not share any type of evolutionary relationship between the other two species. It formed as a unique species in all the three phylogenetic trees, thus provides a clear-cut view that Oscar does not have any kind of evolutionary relationship with the tilapia species.

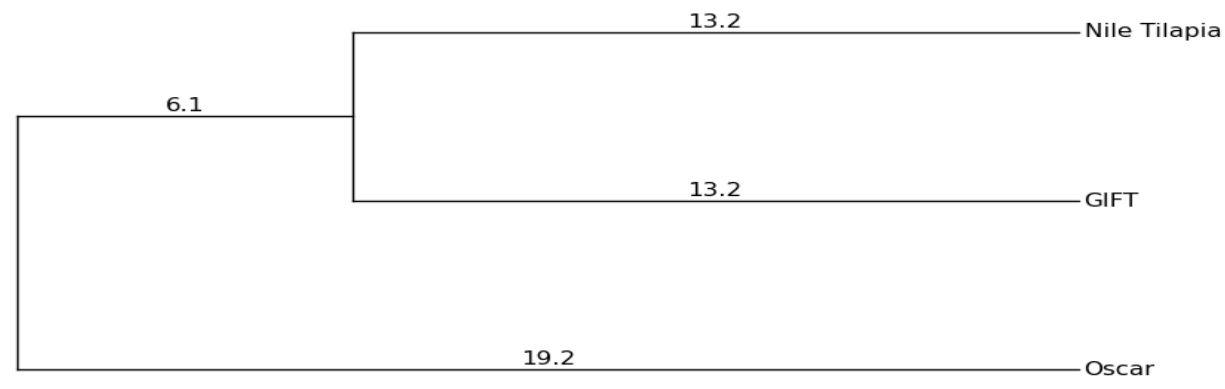

(a)

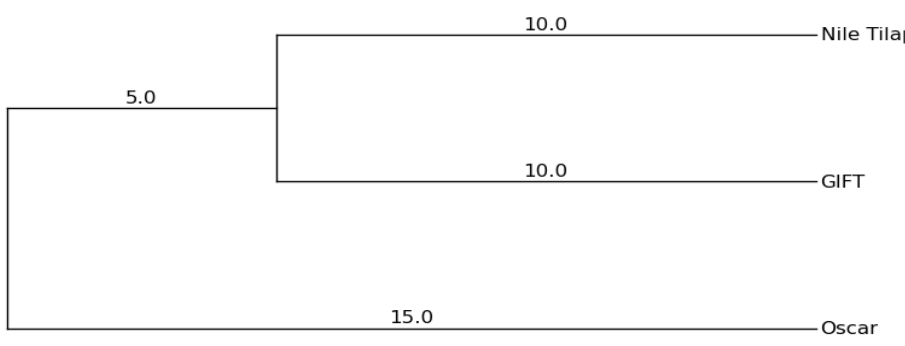

(b)

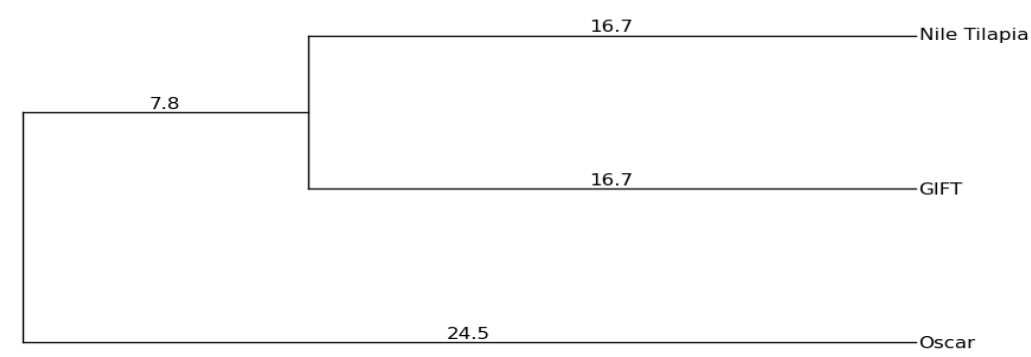

(c)

Figure 5. The phylogenetic tree of three species of cichlid fishes (GIFT, Oreochromis niloticus (Nile tilapia), Astronotus ocellatus (Oscar)) using three different primers: (a) OPA10; (b) OPA08; (c) OPA04. 


\subsection{PCR amplification.}

The amplified 18S rRNA gene from GIFT, Oreochromis niloticus (Nile tilapia), Astronotus ocellatus (Oscar) was done using the primers SSU I and SSU II. The primer details of SSU I and SSU II are listed in Table 4. The 18S rRNA gene was selected because it reveals even genetic variation between the species [25]. The PCR product's visualization was electrophoresed on a $1.5 \%$ agarose gel stained with ethidium bromide was shown in Figure 6. However, many workers have used mitochondrial DNA as a marker in fish species identification. This was previously used to amplify mitochondria DNA in tuna species. However, Nakajima et al. used the primers, $18 \mathrm{~S}$ forward primer (5'CCG CTT TGG TGA CTC TTG AT) and $18 \mathrm{~S}$ reverse primer (5'CCG AGG ACC TCA CTA AAC CA) to amplify $18 \mathrm{~S}$ rRNA gene-based on the sequence information of channel catfish [27]. In the present study, $1800 \mathrm{bp}$ and $1400 \mathrm{bp}$ of the 18S rRNA gene of cichlid species were amplified by PCR using three different primers OPA10, OPA08, and OPA04.

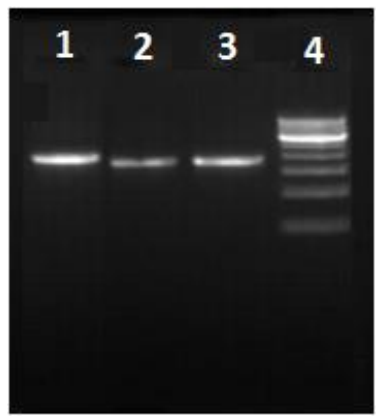

Figure 6. The 18S rRNA gene amplified products of GIFT (Lane 1), Oreochromis niloticus (Lane 2), Astronotus ocellatus (Lane 3).

Table 4. Details of the primers used for the amplification of 18S rRNA gene.

\begin{tabular}{l|l|l|l|l} 
S.No & Primer Name & Primer Sequence & GC $\%$ & $\mathbf{T}_{\mathbf{m}}\left({ }^{\circ} \mathbf{C}\right)$ \\
\hline 1 & SSU I & CGACTGGTTGATCCTGCCAGTAG & 56.5 & 68.9 \\
\hline 2 & SSU II & TCCTGATCCTTCTCAGGTTCAC & 50 & 64.4
\end{tabular}

3.6. RFLP analysis.

RFLP analysis was done with three restriction enzymes, namely AvaI, EcoRI, and SmaI for Nile tilapia, GIFT, and Oscar cichlid for the 18S rRNA extracted from the samples. RFLP analysis was done to find the genetic variations and the phylogenetic relationship between the three species. Each enzyme was used for the three samples, and obtained results were observed using the UV transilluminator mentioned in Figure 7.

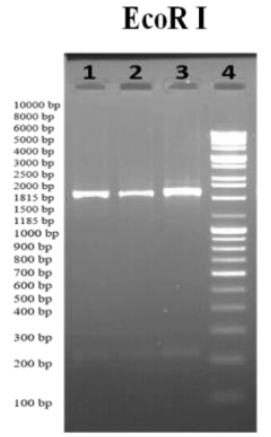

(a)

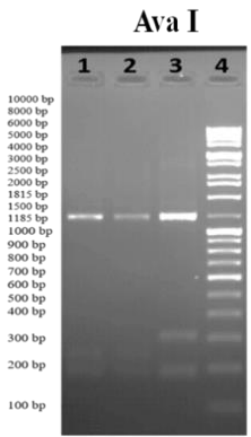

(b)

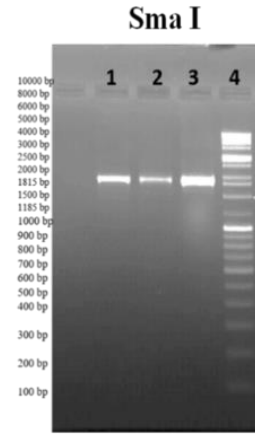

(c)

Figure 7. RAPD analysis of 18S rRNA gene from GIFT (Lane 1), Oreochromis niloticus (Lane 2), Astronotus ocellatus (Lane 3) using three restriction enzymes: (a) EcoRI; (b) AvaI; (c) SmaI. 
The restriction digestion of $18 \mathrm{~S}$ rRNA gene of Nile Tilapia with AvaI restriction endonuclease resulted in three restriction fragments (1067 bp, $377 \mathrm{bp}$, and $351 \mathrm{bp}$ ). It yielded the same result for GIFT Tilapia (1067 bp, $361 \mathrm{bp}$, and $348 \mathrm{bp}$ ). Contradictory to the present study's findings, AvaI generated 6 restriction fragments after digestion with 18S rRNA gene of Nile Tilapia (650 bp, 500 bp, 350 bp, 250 bp, 150 bp, 100 bp). In the present study, AvaI generated similar bands for GIFT tilapia also. However, in the case of Oscar, AvaI generated 5 bands with the molecular size of $3192 \mathrm{bp}, 1516 \mathrm{bp}, 1067 \mathrm{bp}, 377 \mathrm{bp}$, and $350 \mathrm{bp}$ with the $\mathrm{R}_{\mathrm{f}}$ values $0.20,0.32,0.36,0.72$, and 0.81 , respectively. The restriction digestion of the $18 \mathrm{~S}$ rRNA gene of the three cichlid finfishes, Nile tilapia, GIFT, and Oscar, did not result in any polymorphic band in Nile and GIFT in Oscar, it generated 3 polymorphic bands. In the present study, the restriction digestion of this amplified 18S rRNA gene with EcoRI resulted in 3 DNA bands of $1921 \mathrm{bp}, 1613 \mathrm{bp}$, and $323 \mathrm{bp}$ with the $\mathrm{R}_{\mathrm{f}}$ values $0.26,0.29$, and 0.76, respectively. Similarly, Nile tilapia and GIFT tilapia resulted in 3 DNA bands of $1882 \mathrm{bp}, 1613 \mathrm{bp}$, and 320 bp with $\mathrm{R}_{\mathrm{f}}$ values of $0.27,0.29$, and 0.77 . While it generated three bands in Oscar cichlids of molecular size $1962 \mathrm{bp}, 169 \mathrm{bp}$, and $322 \mathrm{bp}$ with $\mathrm{R}_{\mathrm{f}}$ values of $0.26,0.29$, and 0.76 . The results of the present study are in agreement with El-Serafy et al.'s results. They observed that EcoR1 digestion of 18S rRNA gene generated only two bands in the four species of tilapia, including Nile tilapia. However, in their study, they observed bands with different molecular sizes (1650 bp and $350 \mathrm{bp}$ ) compared with the present study results [26].

EcoRI generated similar bands in GIFT tilapia and Nile tilapia, and no polymorphic band was found between them. However, in Oscar, it generated a total of 3 bands with only one polymorphic band with a molecular size of 1962 bp with the $R_{f}$ value of 0.26. Similar results were reported by El-Serafy et al., who observed that SmaI did not digest the 18S rRNA gene of the three tilapia species, O.niloticus, O.aureus, and S.galilaeus [26].

\section{Conclusions}

The present study was done to show the evolutionary relationship between three different cichlid finfishes (Nile Tilapia, GIFT, and Oscar cichlid). The genomic DNA was extracted from the caudal fin tissues of these three fishes (Nile Tilapia, GIFT, and Oscar Cichlid). These relationships were studied with the help of RFLP and RAPD techniques. The RFLP analysis was done with the help of three enzymes, and bands were visualized. RFLP analysis showed that there were genetic variations after a certain point. The movement of the DNA was visualized under UV transilluminator. The $R_{f}$ value and molecular weight of the samples were calculated for both RAPD and RFLP analysis. The phylogenetic tree was constructed by using software called PyElph, and the phylogenetic relationships were studied. The study proved an evolutionary relationship among the three cichlid fin fishes, and it also showed the genetic variations occurring among these fishes (Nile Tilapia, GIFT, and Oscar Cichlid). There have been various genetic variations among the fishes from one generation to another in the given analysis. The phylogenetic tree proved that Nile Tilapia and GIFT shared recent common ancestors.

\section{Funding}

This research received no external funding. 


\section{Acknowledgments}

This research has no acknowledgment.

\section{Conflicts of Interest}

The authors declare no conflict of interest.

\section{References}

1. Mohanty, B.P.; Mahanty, A.; Ganguly, S.; Mitra, T.; Karunakaran, D.; Anandan, R. Nutritional composition of food fishes and their importance in providing food and nutritional security. Food Chem. 2019, 293, 561570, https://doi.org/10.1016/j.foodchem.2017.11.039.

2. Marques, I.; Botelho, G.; Guiné, R. Comparative study on nutritional composition of fish available in Portugal. Nutr. Food Sci. 2019, 49, 925-941, https://doi.org/10.1108/NFS-11-2018-0311.

3. Abraha, B.; Admassu, H.; Mahmud, A.; Tsighe, N.; Shui, X.W.; Fang, Y. Effect of processing methods on nutritional and physico-chemical composition of fish: a review. MOJ Food Process Technol. 2018, 6, 376382, https://doi.org/10.15406/mojfpt.2018.06.00191.

4. Volkoff, H.; Ronnestad, I. Effects of temperature on feeding and digestive processes in fish. Temperature 2020, 7, 307-320, https://doi.org/10.1080/23328940.2020.1765950.

5. Urbina, M.A.; Glover, C.N. Effect of salinity on osmoregulation, metabolism and nitrogen excretion in the amphidromous fish, inanga (Galaxias maculatus). J. Exp. Mar. Biol. Ecol. 2015, 473, 7-15, https://doi.org/10.1016/j.jembe.2015.07.014.

6. Mozanzadeh, M.T.; Safari, O.; Oosooli, R.; Mehrjooyan, S.; Najafabadi, M.Z.; Hoseini, S.J.; Saghavi, H.; Monem, J. The effect of salinity on growth performance, digestive and antioxidant enzymes, humoral immunity and stress indices in two euryhaline fish species: Yellowfin seabream (Acanthopagrus latus) and Asian seabass (Lates calcarifer). Aquaculture 2021, https://doi.org/10.1016/j.aquaculture.2020.736329.

7. Ip, Y.; Chew, S.F. Ammonia production, excretion, toxicity, and defense in fish: a review. Front. Physiol. 2010, 1 , https://doi.org/10.3389/fphys.2010.00134.

8. Shin, K.W.; Kim, S.H.; Kim, J.H.; Hwang, S.D.; Kang, J.C. Toxic effects of ammonia exposure on growth performance, hematological parameters, and plasma components in rockfish, Sebastes schlegelii, during thermal stress. Fish. Aquatic Sci. 2016, 19, https://doi.org/10.1186/s41240-016-0044-6.

9. Magouz, F.I.; Mahmoud, S.A.; El-Morsy, R.A.A.; Paray, B.A.; Soliman, A.A.; Zaineldin, A.I.; Dawood, M.A.O. Dietary menthol essential oil enhanced the growth performance, digestive enzyme activity, immunerelated genes, and resistance against acute ammonia exposure in Nile tilapia (Oreochromis niloticus). Aquaculture 2021, 530, https://doi.org/10.1016/j.aquaculture.2020.735944.

10. Makori, A. J.; Abuom, P. O.; Kapiyo, R.; Anyona, D.N.; Dida, G.O. Effects of water physico-chemical parameters on tilapia (Oreochromis niloticus) growth in earthen ponds in Teso North Sub-County, Busia County. Fish. Aquatic Sci. 2017, 20, https://doi.org/10.1186/s41240-017-0075-7.

11. Dawood, M.A.O.; Zommara, Eweedah, N.M.; Helal. A.I. Synergistic effects of selenium nanoparticles and vitamin $\mathrm{E}$ on growth, immune-related gene expression, and regulation of antioxidant status of Nile tilapia (Oreochromis niloticus). Biol. Trace Elem. Res. 2020, 195, 624-635, https://doi.org/10.1007/s12011-01901857-6/

12. Mohamed, N.A.; Saad, M.F.; Shukry, M.; El-Keredy, A.M.S.; Nasif, O.; Doan, H.V.; Dawood, M.A.O. Physiological and ion changes of Nile tilapia (Oreochromis niloticus) under the effect of salinity stress. Aquac. Rep. 2021, 19, https://doi.org/10.1016/j.aqrep.2020.100567.

13. Obirikorang, K.A.; Asante-Tuoh, D.T.; Agbo, N.W.; Amponsah, A.K.; Skov, P.V. Anaesthetic potential of propofol for nile tilapia (Oreochromis niloticus): Effect of anaesthetic concentration and body weight. Scientific African 2020, 10, https://doi.org/10.1016/j.sciaf.2020.e00595.

14. Singha, K.P.; Shamna, N.; Sahu, N.P.; Sardar, P., Harikrishna, V., Thirunavukkarasar, R.; Chowdhury, D.K.; Maiti, M.K.; Krishna, G. Optimum dietary crude protein for culture of genetically improved farmed tilapia (GIFT), Oreochromis niloticus (Linnaeus, 1758) juveniles in low inland saline water: Effects on growth, metabolism and gene expression. Anim. Feed Sci. Technol. 2021, 271, https://doi.org/10.1016/j.anifeedsci.2020.114713.

15. Tran, N.; Shikuku, K.M.; Rossignoli, C.M.; Barman, B.K.; Ching, C.K.; Ali, M.S.; Benzie, J.A.H. Growth, yield and profitability of genetically improved farmed tilapia (GIFT) and non-GIFT strains in Bangladesh. Aquaculture 2021, 536, https://doi.org/10.1016/j.aquaculture.2021.736486.

16. Nguyen, L.; Dinh, H.; Davis, D.A. Efficacy of reduced protein diets and the effects of indispensable amino acid supplements for Nile tilapia Oreochromis niloticus. Anim. Feed Sci. Technol. 2020, 268, https://doi.org/10.1016/j.anifeedsci.2020.114593. 
17. Abdel-Latif, H.M.R.; Soliman, A.A.; Sewilam, H.; Almeer, R.; Doan, H.V.; Alagawany, M.; Dawood, M.A.O. The influence of raffinose on the growth performance, oxidative status, and immunity in Nile tilapia (Oreochromis niloticus). Aquacult. Rep. 2020, 18, https://doi.org/10.1016/j.aqrep.2020.100457.

18. Sgnaulin, T.; Durigon, E.G.; Pinho, S.M.; Jerônimo, G.T.; de Alcantara Lopes, D.L.; Emerenciano, M.G.C. Nutrition of Genetically Improved Farmed Tilapia (GIFT) in biofloc technology system: Optimization of digestible protein and digestible energy levels during nursery phase. Aquaculture 2020, 521, https://doi.org/10.1016/j.aquaculture.2020.734998.

19. Miao, L.; Charles, O.; Lin, Y.; Gong, Y.; Zhu, W.; Wang, L.; Fu, J.; Zhang, Z.; Dong, Z. Interactive effects of mulberry leaf meal and bamboo charcoal additive on growth performance, anti-oxidant capacity, and disease resistance of genetically improved farmed tilapia (GIFT) juvenile (Oreochromis niloticus). Aquacult. Rep. 2020, 18, https://doi.org/10.1016/j.aqrep.2020.100483.

20. Singha, K.P.; Shamna, N.; Sahu, N.P.; Sardar, P.; HariKrishna, V.; Thirunavukkarasar, R.;Kumar, M.; Krishna, G. Feeding graded levels of protein to Genetically Improved Farmed Tilapia (GIFT) juveniles reared in inland saline water: Effects on growth and gene expression of IGF I, IGF-IR and IGF-BPI. Aquaculture 2020, 525, https://doi.org/10.1016/j.aquaculture.2020.735306.

21. De Carvalho, A.F.S.; Assis, I.de L.; Paiva, I.M.; Mansur, V.F.R.; Castro, T.F.D.; Felizardo, V. de O.; Bruhn, F.R.P.; Murgas, L.D.S. Identification of sex in Astronotus ocellatus through the evaluation of aggressive behavior and sexual steroid plasma level. Aquaculture 2017, 481, 239-244, https://doi.org/10.1016/j.aquaculture.2017.09.010.

22. Bardakci, F.; Skibinski, D.O.F. Application of the RAPD technique in tilapia fish: species and subspecies identification. Heredity 1994, 73, 177-123, https://doi.org/10.1038/hdy.1994.110.

23. Ahmed, M.M.M.; Ali, B.A.; El-Zaeem, S. Application of RAPD markers in fish: part I- Some genera (Tilapia, Sarotherodon and Oreochromis) and species (Oreochromis aureus and Oreochromis niloticus) of tilapia. Int. J. Biotechnol. 2004, 6, 86-93, https://doi.org/10.1504/IJBT.2004.004615.

24. Pavel, A.B.; Vasile, C.I. PyElph - a software tool for gel images analysis and phylogenetics. BMC Bioinformatics 2012, 13, https://doi.org/10.1186/1471-2105-13-9.

25. Stothard, J.R.; Rollinson, D. Molecular characterization of Bulinus globosus and B. nasutus on Zanzibar, and an investigation of their roles in the epidemiology of Schistosoma haematobium. Trans. Royal Soc. Trop. Med. Hyg. 1997, 91, 353-357, https://doi.org/10.1016/s0035-9203(97)90105-x.

26. El-Serafy, S.S.; Awwad, M.H.; Abd-El-Hameid, N.H.; Azab, M.S. Restriction Fragment Length polymorphisms (RFLPs) of the small subunit ribosomal DNA as a tool for identification of Tilapia spp. Egyp. J. of Aq. Biol. Fish. 2003, 7, 465-482.

27. Nakajima, R.T.; Diogo, C.C.; Valente, G.T.; Venere, P.C.; Martins, C. Evolutionary dynamic of rRNA gene clusters in cichlid fish. BMC Evol. Biol. 2012, 12, https://doi.org/10.1186/1471-2148-12-198. 